Article

\title{
Correlation between H-ZSM-5 crystal size and catalytic performance in the methanol-to-aromatics reaction
}

\author{
Lingzhi Yang, Zhiyuan Liu, Zhi Liu, Wenyong Peng, Yunqi Liu *, Chenguang Liu \# \\ State Key Laboratory of Heavy Oil Processing, College of Chemical Engineering, China University of Petroleum (East China), Qingdao 266580, Shandong, \\ China
}

A R T I C L E I N F O

Article history:

Received 29 November 2016

Accepted 13 January 2017

Published 5 April 2017

\section{Keywords:}

Methanol

Aromatics

Nano-sized H-ZSM-5

Hierarchical structure

Crystal size

\begin{abstract}
A B S T R A C T
The porosity of H-ZSM-5 zeolite is known to facilitate the diffusion of molecules in the methanol-to-aromatics (MTA) reaction. The activity and selectivity of the H-ZSM-5 catalyst in the MTA reaction has been studied as a function of crystal size. ZSM-5 zeolites with different crystal sizes were successfully synthesized by conventional hydrothermal methods. Tailoring ZSM-5 particle size was easily controlled by changes to the sol-gel composition, and in particular, the deionized water to tetrapropylammonium hydroxide ratio, and crystallization time. The structure of the H-ZSM-5 zeolites were characterized by X-ray diffraction and the morphology of the zeolite particles was determined by scanning electron microscopy. $\mathrm{N}_{2}$ adsorption-desorption measurements established changes to the textural properties, and compositional properties were characterized by X-ray fluorescence spectroscopy. Acidity measurements of the catalysts were measured by pyridine-adsorbed Fourier transform infrared spectroscopy and the temperature-programmed desorption of ammonia. After subjecting the catalysts to the MTA reaction, the total amount of coke formed on the spent deactivated catalysts was determined by thermal gravimetric analysis. The results show that the $\mathrm{SiO}_{2} / \mathrm{Al}_{2} \mathrm{O}_{3}$ molar ratios and acidic properties of the H-ZSM-5 samples are similar, however, the nano-sized hierarchical ZSM-5 zeolite with an additional level of auxiliary pores possesses a higher surface area, larger mesopore volume and larger macropore volume, resulting in more effective mass transportation properties. The H-ZSM-5 zeolite catalysts were evaluated for their activity towards the MTA reaction as a function of crystal size. The nano-sized H-ZSM-5 catalyst having shorter diffusion path lengths, substantial mesoporosity and a high external surface area showed excellent selectivity toward aromatics (average $>42 \%$ ) and benzene, toluene and xylenes (37\% at $180 \mathrm{~min}$ ). Furthermore, lower coking levels were observed on the nano-sized H-ZSM-5 catalyst when compared with the H-ZSM-5 catalysts possessing larger particle sizes and is attributed to a reduction in polyaromatic hydrocarbons being deposited within the internal surface area.
\end{abstract}

(C) 2017, Dalian Institute of Chemical Physics, Chinese Academy of Sciences. Published by Elsevier B.V. All rights reserved.

\section{Introduction}

Aromatics largely produced by petrochemical processes such as the cracking and reforming of petroleum are very im- portant raw materials for the chemical industry [1]. The development of new technologies stemming from renewable sources to meet the increasing demand of aromatics, especially benzene, toluene, and xylene (BTX), is gaining importance be-

\footnotetext{
* Corresponding author. Tel: +86-532-86981861; E-mail: liuyq@upc.edu.cn

\# Corresponding author. Tel: +86-532-86981716; E-mail: cgliu@upc.edu.cn

This work was supported by the National Natural Science Foundation of China (21676300).

DOI: 10.1016/S1872-2067(17)62791-8 | http://www.sciencedirect.com/science/journal/18722067 | Chin. J. Catal., Vol. 38, No. 4, April 2017
} 
cause of fossil fuel depletion [2-5]. In recent years, the aromatization of methanol has been receiving ever-increasing attention because of the wide availability of methanol, which is currently produced from coal, natural gas and biomasses [6-9]. ZSM-5 zeolites can be used as catalysts for the methanol-to-aromatics (MTA) reaction because of their large surface areas, tunable acidity, shape-selective properties, and high hydrothermal stability [10-13]. The acidity of ZSM-5 is a principal property affecting the nature of products, and is generally tuned by tailoring of the framework $\mathrm{Si} / \mathrm{Al}$ molar ratio $[14,15]$. The tortuosity of ZSM-5 is another important property that facilitates molecular diffusion behavior. Nano-sized ZSM-5 possesses an additional layer of auxiliary porosity because of inter-crystalline voids, resulting in improved diffusion [16].

Numerous works have reported enhanced catalytic performance of nano-sized ZSM-5 when compared with their larger sized analogues. Viswanadham et al. $[17,18]$ reported that nano-sized ZSM-5 exhibited very high activity in the esterification of cyclohexanol with acetic acid, and enhanced catalytic performance in the acetone-to-gasoline reaction. According to Firoozi and coworkers [19], nano-sized H-ZSM-5 showed higher activity and stability compared with the micro-sized H-ZSM-5 in the methanol-to-propylene reaction. Choi et al. [20] synthesized stable MFI zeolite single-unit-cell nanosheets, which were active and long-lived in methanol-to-gasoline reactions. Shen et al. [11,21] prepared nano-sized ZSM-5 under atmospheric pressure with high crystallinity, large surface area, uniform size and excellent catalytic performance for the MTA reaction compared with conventional ZSM-5.

However, there are limited reports investigating the MTA reaction performance as a function of H-ZSM-5 crystal size. In this paper, a systematic study has been designed to synthesize H-ZSM-5 zeolites having different crystal sizes to elucidate how H-ZSM- 5 activity and selectivity in the MTA reaction is affected by crystal size.

\section{Experimental}

\subsection{Synthesis of H-ZSM-5 with different crystal sizes}

All reagents used for the ZSM-5 preparation were purchased from Sinopharm Chemical Reagent Co., Ltd, China. ZSM-5 samples with different crystal sizes were prepared using tetrapropylammonium hydroxide (ТPAOH, $25 \mathrm{wt} \%$ ) as the templating agent, tetraethyl orthosilicate (TEOS, $28.4 \mathrm{wt} \%$ ) as the silica source, $\mathrm{Al}\left(\mathrm{NO}_{3}\right)_{3} \cdot 9 \mathrm{H}_{2} \mathrm{O}(99 \mathrm{wt} \%)$ as the alumina source, $\mathrm{NaOH}$ (96 wt\%) and deionized water. A sol-gel was prepared with a molar composition of: 5-15 TPAOH: $0.5 \mathrm{Al}_{2} \mathrm{O}_{3}$ : $25 \mathrm{SiO}_{2}$ : $500 \mathrm{H}_{2} \mathrm{O}: 0.075 \mathrm{Na}_{2} \mathrm{O}$ and was stirred for $2 \mathrm{~h}$ at room temperature before being transferred into a Teflon-lined autoclave and pre-treated at $120^{\circ} \mathrm{C}$ for $2 \mathrm{~h}$ followed by hydrothermal treatment at $180{ }^{\circ} \mathrm{C}$ for $24-72 \mathrm{~h}$. All synthesized samples were separated from the mother liquor by centrifugation, washed with deionized water, and dried at $120^{\circ} \mathrm{C}$ for $6 \mathrm{~h}$. The zeolites were rendered porous by template removal through calcination at $550^{\circ} \mathrm{C}$ in air for $4 \mathrm{~h}$.

The calcined Na-zeolites were ion-exchanged twice with a
$\mathrm{NH}_{4} \mathrm{NO}_{3}(99 \mathrm{wt} \%)$ solution $(0.3 \mathrm{~mol} / \mathrm{L}$, liquid/solid ratio $=20: 1$ $\mathrm{mL} / \mathrm{g}$ ) at $80{ }^{\circ} \mathrm{C}$. Thereafter, the $\mathrm{NH}_{4}$-zeolite samples were washed, filtered, and dried at $120{ }^{\circ} \mathrm{C}$ for $6 \mathrm{~h}$. Finally, the samples were calcined at $550^{\circ} \mathrm{C}$ for $4 \mathrm{~h}$ to obtain H-ZSM- 5 zeolites.

\subsection{Physico-chemical characterization}

X-ray diffraction (XRD) patterns of the samples were obtained using a PANalytical X'Pert PRO MPD diffractometer applying $\mathrm{Cu}-K_{\alpha}$ radiation $(\lambda=0.15406 \mathrm{~nm})$ generated at $40 \mathrm{kV}$ and $30 \mathrm{~mA}$. Sample morphology and crystal size were determined by scanning electron microscopy (SEM) using a FEI Sirion 200 microscope operating at an acceleration voltage of $10 \mathrm{kV} . \mathrm{N}_{2}$ adsorption-desorption isotherms were measured using an ASAP-2020 instrument (Micrometrics, USA) at $-196{ }^{\circ} \mathrm{C}$. Dead space was measured using helium gas. Surface areas, pore volumes and pore size distributions were calculated by measuring the volume adsorbed at different relative pressures [14]. Pyridine-adsorbed Fourier transform infrared (FT-IR) spectra were recorded using a VERTEX 70 FT-IR spectrometer (Bruker, Germany). The catalyst samples were first dried at $300{ }^{\circ} \mathrm{C}$ under $\mathrm{N}_{2}$ for $4 \mathrm{~h}$, prior to cooling to room temperature, before being subjected to a saturated pyridine atmosphere for $12 \mathrm{~h}$ to allow adsorption. Thereafter, the samples were exposed to pure $\mathrm{N}_{2}$ at $110{ }^{\circ} \mathrm{C}$ for $4 \mathrm{~h}$ to remove the physically absorbed pyridine. The $\mathrm{NH}_{3}$-temperature-programed desorption (TPD) curves were obtained in the range of $70-700{ }^{\circ} \mathrm{C}$ having a ramp of $10{ }^{\circ} \mathrm{C} / \mathrm{min}$ (Quantachrome Chembet-3000). The adsorption of ammonia on the samples was performed at $70{ }^{\circ} \mathrm{C}$, followed by ammonia removal in a flow of pure helium. $\mathrm{SiO}_{2} / \mathrm{Al}_{2} \mathrm{O}_{3}$ molar ratios of the ZSM-5 zeolites were determined using a PANalytical Axios Petro X-ray fluorescence (XRF) instrument.

\subsection{Catalytic testing}

The as-synthesized H-ZSM-5 zeolites were pressed into wafers and then crushed and sieved to 20-40 mesh particle size before use. The catalytic activity tests for the MTA reaction were performed in a fixed-bed continuous flow reactor with an inner diameter of $8.5 \mathrm{~mm}$ under the following conditions: $\mathrm{N}_{2}$ pressure of $0.5 \mathrm{MPa}$, temperature of $450{ }^{\circ} \mathrm{C}$, weight hourly space velocity (WHSV) of $2 \mathrm{~h}^{-1}$, and a catalyst loading of $5 \mathrm{~mL}$ ( $3.325 \mathrm{~g}$ ). After a stabilizing period of $2 \mathrm{~h}$, the reaction product was removed from the reactor for further analysis. The product obtained at the end of the reaction was cooled using a cold-water circulator, where the entire product was separated into liquid products and gas products. The liquid products contained both aqueous and oil phase components. The oil products were analyzed using an Agilent 7890N gas chromatograph (GC) system. The aqueous phase products were analyzed using an Agilent 6820-GC system. The gas phase products were collected in a syringe and analyzed using a Bruker 450-GC system. The total amount of coke formed on the deactivated spent catalysts was determined by thermal gravimetric (TG) analysis using a Netzsch STA 449 F3 instrument in air at a heating rate of $10^{\circ} \mathrm{C} / \mathrm{min}$ from room temperature to $\sim 800{ }^{\circ} \mathrm{C}$.

The reaction performance was assessed by methanol con- 


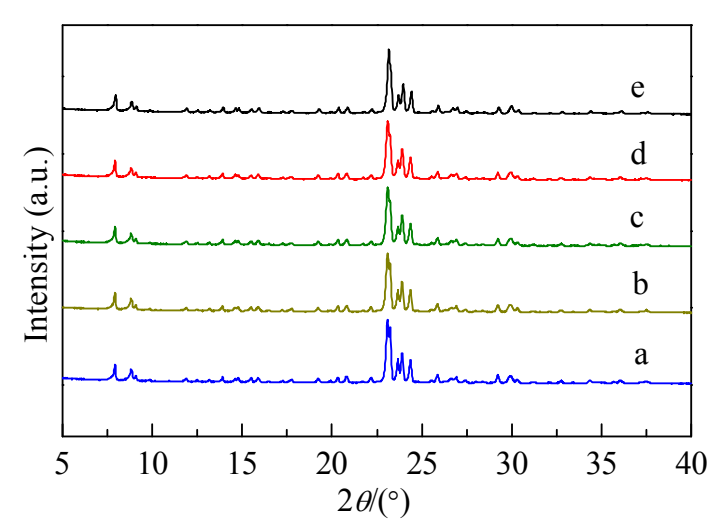

Fig. 1. XRD patterns of the ZSM-5 zeolite samples a-e.

version and aromatic product selectivity according to the following formulas:

$$
\begin{gathered}
X_{\mathrm{MeOH}}=\left(n_{\mathrm{MeOH}, \text { in }}-n_{\mathrm{MeOH}, \text { out }}\right) / n_{\mathrm{MeOH}, \text { in }} \times 100 \% \\
S_{\text {Aro. }}=m_{\text {Aro }} /\left(\left(n_{\mathrm{MeOH}, \text { in }}-n_{\mathrm{MeOH}, \text { out }}\right) \times 14\right) \times 100 \% \\
S_{\mathrm{BTX}}=m_{\mathrm{BTX}} / m_{\text {Aro }} \times 100 \% \\
S_{\text {Aro }, i}=m_{\text {Aro, } i} / m_{\text {Aro }} \times 100 \%
\end{gathered}
$$

where $X_{\mathrm{MeOH}}$ is the conversion of methanol, $S_{\text {Aro }}$ is the selectivity for aromatics, $S_{\mathrm{BTX}}$ represents the selectivity for BTX, $S_{\mathrm{Aro}, i}$ is the selectivity for target aromatic product $i$ ( $i=$ benzene, toluene, xylene and $\mathrm{C}_{9}{ }^{+}$aromatics), $n_{\mathrm{MeOH}}$, in and $n_{\mathrm{MeOH}}$ out represent the number of moles of methanol passing the inlet and outlet streams, respectively, and $m_{\mathrm{Aro}}, m_{\mathrm{BTX}}$, and $m_{\mathrm{Aro}, i}$ represent the mass of aromatics, BTX and aromatic product $i$ in the product stream, respectively.

\section{Results and discussion}

Table 1

Structural and textural properties of H-ZSM- 5 catalyst samples.

\begin{tabular}{lccccc}
\hline Sample & $\begin{array}{c}\text { Relative crystallinity } \\
(\%)\end{array}$ & $\begin{array}{c}A_{\text {BET }}{ }^{\mathrm{a}} \\
\left(\mathrm{m}^{2} / \mathrm{g}\right)\end{array}$ & $\begin{array}{c}\left.V_{\text {micro }}{ }^{\mathrm{b}} \mathrm{cm}^{3} / \mathrm{g}\right) \\
\left(\mathrm{cm}^{3} / \mathrm{g}\right)\end{array}$ & $\begin{array}{c}V_{\text {meso }}{ }^{\mathrm{c}} \\
\mathrm{SiO}_{2} / \mathrm{Al}_{2} \mathrm{O}_{3} \\
\text { molar ratios }^{\mathrm{d}}\end{array}$ \\
\hline $\mathrm{a}$ & 100 & 294 & 0.12 & 0.06 & 51 \\
$\mathrm{~b}$ & 96 & 343 & 0.15 & 0.06 & 51 \\
$\mathrm{c}$ & 91 & 354 & 0.15 & 0.07 & 50 \\
$\mathrm{~d}$ & 94 & 378 & 0.16 & 0.08 & 45 \\
$\mathrm{e}$ & 95 & 383 & 0.17 & 0.24 & 55 \\
\hline
\end{tabular}

${ }^{a}$ Brunauer-Emmett-Teller (BET) surface area; ${ }^{\mathrm{b}}$ micropore volume determined by t-plot; c mesopore volume calculated as $V_{\text {total }}-V_{\text {micro; }}$; ${ }^{\mathrm{d}}$ measured by XRF.

\subsection{Structural and textural properties}

The powder XRD patterns of the prepared ZSM-5 samples are shown in Fig. 1. It can be seen that all the samples exhibit the typical diffraction peaks which are characteristic of the ZSM-5 framework (MFI) structure. Across all five samples the XRD patterns have a very low background signal and sharp reflections indicating their superior crystalline properties. However, there are differences in the diffractograms between the prepared ZSM-5 zeolites as peak intensities decrease and line widths increase from sample a to e, suggesting a decrease in crystal size from sample a to sample e [21,22]. The degree of crystallinity was estimated by comparing the total XRD peak area normalized to sample a over the $2 \theta$ range from $7^{\circ}$ to $25^{\circ}$, as shown in Table 1. Fig. 2 shows the SEM micrographs and corresponding particle size distributions of the as-synthesized ZSM-5 zeolites. The results illustrate that the as-synthesized ZSM-5 zeolites exhibit cuboid-like particle morphology, which vary in size as a function of the sol-gel composition. From Fig. 2(a)-(e), it is clear that particle size reduces from sample a to sample e. The corresponding particle sizes are: $4.0 \pm 0.3,1.2 \pm$

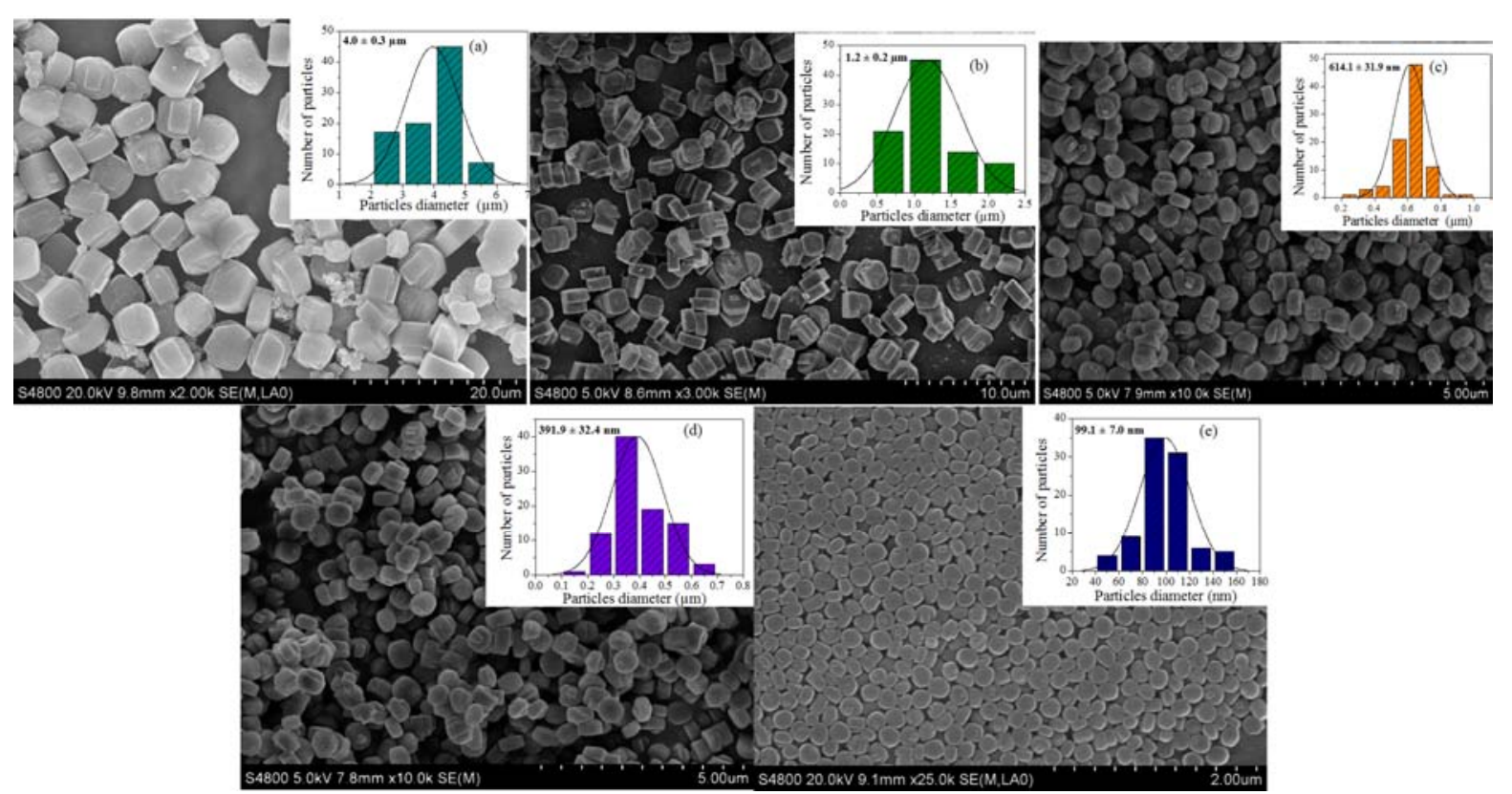

Fig. 2. SEM images of ZSM- 5 zeolite samples with corresponding particle size distribution charts. (a) sample a ( $4.0 \pm 0.3 \mu \mathrm{m})$; (b) sample b (1.2 \pm 0.2 $\mu \mathrm{m})$; (c) sample c $(614.1 \pm 31.9 \mathrm{~nm})$; (d) sample d $(391.9 \pm 32.4 \mathrm{~nm})$; (e) sample e $(99.1 \pm 7.0 \mathrm{~nm})$. 


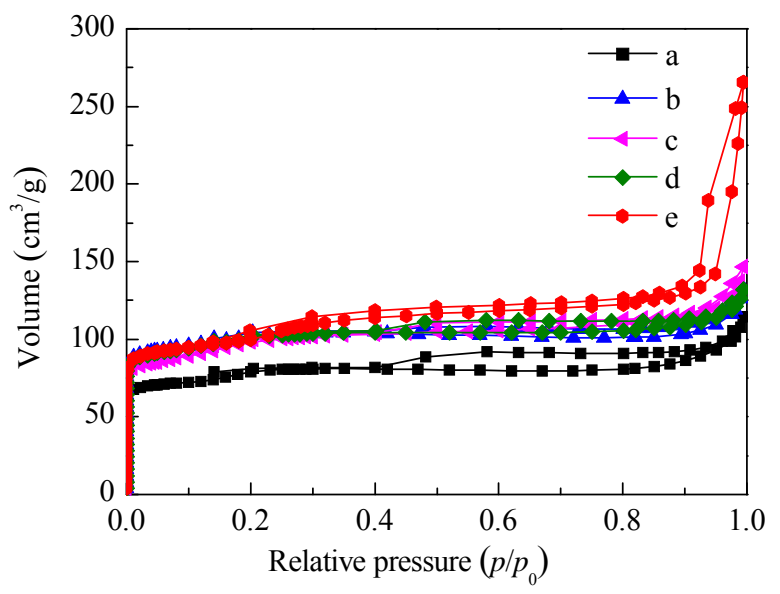

Fig. 3. $\mathrm{N}_{2}$ adsorption-desorption isotherms of $\mathrm{H}-\mathrm{ZSM}-5$ samples a-e.

$0.2 \mu \mathrm{m}, 614.1 \pm 31.9,391.9 \pm 32.4$, and $99.1 \pm 7.0 \mathrm{~nm}$, respectively.

As shown in Fig. 3, the $\mathrm{N}_{2}$ adsorption-desorption isotherms of samples a-d exhibit type I physisorption corresponding to a typical microporous structure, while sample e exhibits type IV physisorption relating to the presence of mesoporosity, according to the IUPAC classification [23]. For the nano-sized H-ZSM-5 zeolite, sample e, there is an apparent type $\mathrm{H} 4$ hysteresis loop because of the presence of both mesopores and macropores at high relative pressure $\left(p / p_{0}=0.8-1.0\right)$ relating to inter-crystalline voids produced by stacking of the nano-sized crystals $[17,24]$. The Barrett-Joyner-Halenda (BJH) method is one model typically employed to determine the mesopore size distribution [25]. The pore size distribution curves of samples a-e, derived from the BJH model using the adsorption branch of the isotherms, are shown in Fig. 4. The nano-sized H-ZSM-5 zeolite, sample e, shows a bi-modal mesoporous size distribution from 2-7 and 20-50 nm. Furthermore, sample e clearly shows the presence of significant macropores ( $>50 \mathrm{~nm}$ ). Table 1 shows the increase in BET surface area from 294 to $383 \mathrm{~m}^{2} / \mathrm{g}$ as a function of decreasing crystal size $(4.0 \pm$

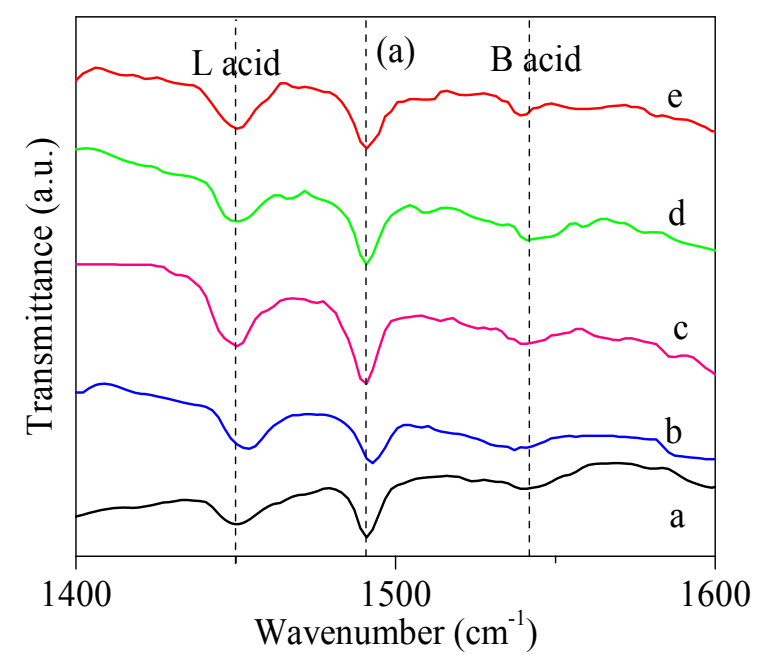

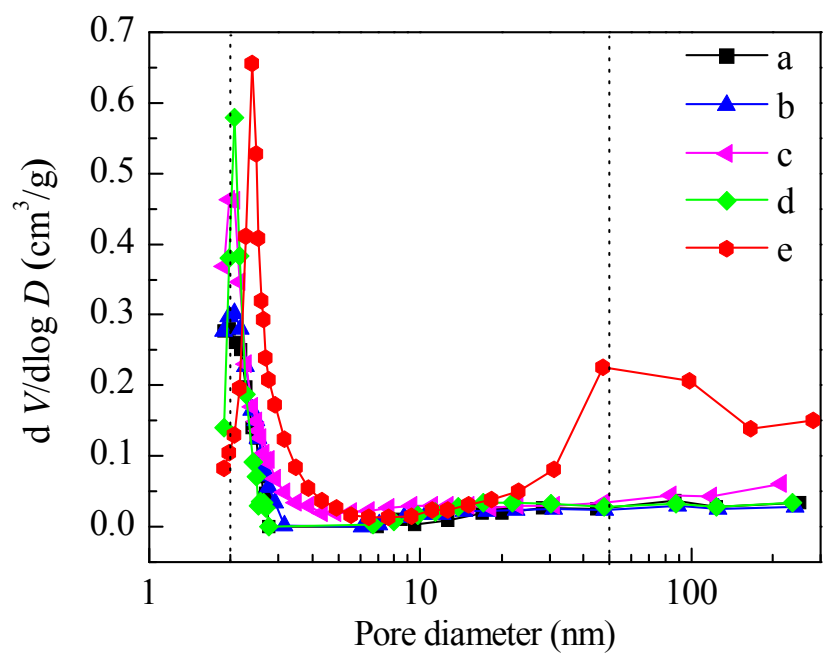

Fig. 4. The BJH adsorption pore size distribution of H-ZSM-5 samples a-e.

$0.3 \mu \mathrm{m}$ to $99.1 \pm 7.0 \mathrm{~nm}$ ). Additionally, there is a corresponding increase in mesopore volume from 0.06 to $0.24 \mathrm{~cm}^{3} / \mathrm{g}$. As a result, the Brunauer-Emmett-Teller (BET) surface area decreases gradually with an increase of ZSM-5 crystal size with the nano-sized ZSM-5 zeolite possessing a significantly larger BET surface area together with a larger mesopore and macropore volume. Furthermore, crystal size can also affect both zeolite textural and surface properties [26].

\subsection{Acidic properties of catalysts}

Py-IR was performed to probe the acid types of the catalysts, and Fig. 5(a) shows the pyridine-adsorbed FT-IR spectra of various H-ZSM-5 catalysts in the region of 1400 to 1600 $\mathrm{cm}^{-1}$. The band at $1450 \mathrm{~cm}^{-1}$ is assigned to pyridine adsorbed on Lewis acid sites, while the band at $1540 \mathrm{~cm}^{-1}$ is ascribed to pyridine adsorbed on Brönsted acid sites. The band at 1490 $\mathrm{cm}^{-1}$ can be attributed to pyridine co-adsorbed on both Lewis and Brönsted acid sites [27]. The results suggest that all the samples have similar numbers of Lewis acid and Brönsted acid

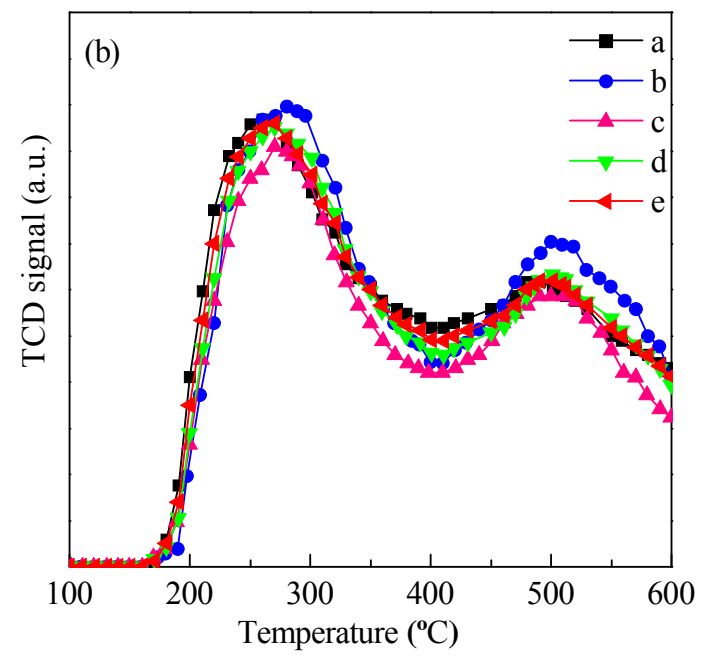

Fig. 5. Pyridine-adsorbed FT-IR spectra (a) and $\mathrm{NH}_{3}$-TPD profiles (b) of various H-ZSM-5 zeolite catalysts. 
sites. Generally, the $\mathrm{NH}_{3}$-TPD spectra of the H-ZSM-5 zeolite catalysts show two main desorption peaks, namely, the low-temperature peak located $<300{ }^{\circ} \mathrm{C}$ and the high-temperature peak at temperatures $>500{ }^{\circ} \mathrm{C}$. The low-temperature peak is ascribed to ammonia adsorbed on weak acid sites, and the high-temperature peak is attributed to strong adsorption sites of ammonia [28]. As shown in Fig. 5(b), the acidic nature of the samples is determined by $\mathrm{NH}_{3}$-TPD, and all the zeolite samples show two peaks centered around 270 and $500{ }^{\circ} \mathrm{C}$. The total acid amount of the samples detected by $\mathrm{NH}_{3}$-TPD are similar, as are the $\mathrm{SiO}_{2} / \mathrm{Al}_{2} \mathrm{O}_{3}$ molar ratios of the samples (Table 1). Thus, the influence of crystal size of the H-ZSM-5 zeolites on the acidic properties is insignificant. Therefore, the impact of crystal size of the H-ZSM- 5 zeolites on the MTA reaction could be studied to assess the effect of the additional auxiliary level of porosity of the nano-sized HZSM-5.

\subsection{Catalytic performance in MTA reaction}

The H-ZSM-5 catalysts were evaluated for their catalytic performance under the same reaction conditions. Fig. 6 shows the MTA catalytic performance as a function of time-on-stream over H-ZSM-5 catalysts having different crystal sizes. As shown in Fig. 6(a), methanol conversion over all H-ZSM-5 catalysts are

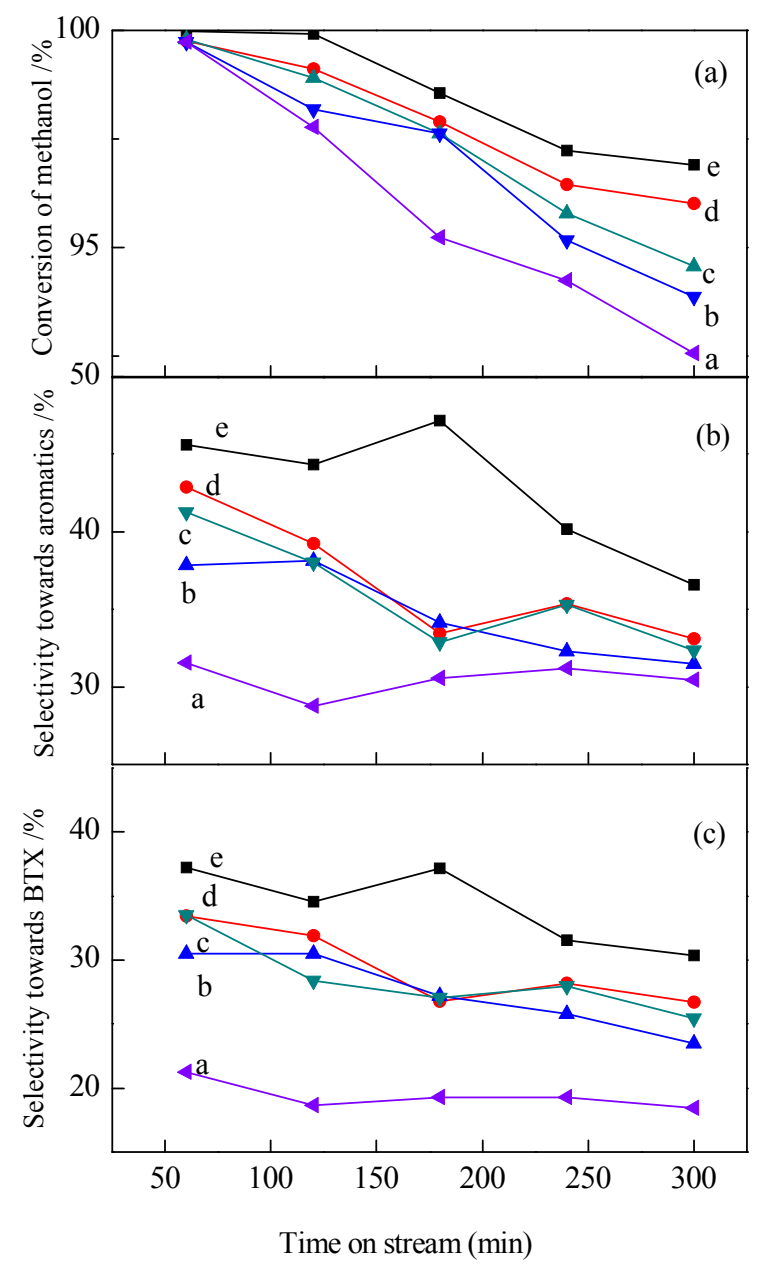

Fig. 6. Methanol conversion (a), selectivity towards aromatics (b) and selectivity towards BTX (c) in MTA reaction. $\sim 100 \%$ after the first 60 min on-stream. However, the initial selectivity for both aromatics and BTX for the nano-sized H-ZSM-5, sample e, is higher than the H-ZSM-5 samples a-d having large particle sizes (Fig. 6(b) and (c)). Catalyst deactivation differs depending on the zeolite particle size. All catalysts show $95 \%$ conversion after 180 min on-stream. Extending the reaction time to beyond 180 min results in varying degrees of methanol conversion. For samples a-c, methanol conversion decreases sharply. However, methanol conversion over sample e is maintained at $>98 \%$ up to $300 \mathrm{~min}$. Additionally, the selectivity toward aromatics and BTX as a function of time-on-stream is given in Fig. 6 (b) and (c), respectively. The selectivity towards aromatics (average $>42 \%$ ) and BTX (37\% at $180 \mathrm{~min}$ ), for sample e, are significantly higher than those for samples a-d. Fig. 7 shows the effect of crystal size on the distribution of aromatic species including BTX and $\mathrm{C}_{9}{ }^{+}$aromatics in the liquid products obtained at 120 min on-stream. Xylene and toluene are the primary aromatic species formed over samples b-e. However, xylene and $\mathrm{C}_{9}{ }^{+}$aromatics are the major aromatic species obtained over sample a, which has the lowest selectivity for aromatics (29\%, Fig. 6), indicating that enhanced diffusion in oversized crystals result in the intermediates to preferentially convert to heavy aromatics, thus tending to generate the coke precursor.

TG measurements on the spent catalysts under flowing air are shown in Fig. 8. In general, the decomposition of coke occurs between 300 and $600{ }^{\circ} \mathrm{C}$, while any adsorbed water is lost before $300^{\circ} \mathrm{C}$. It is evident that weight loss over the deactivated catalyst sample a is significantly higher than that over deactivated catalyst sample e, with the latter converting significantly more methanol (Fig. 5). These results indicate that the nano-sized H-ZSM-5 catalyst possesses short pore channels, which facilitate the rapid diffusion of reactants and products inside the micropores, thus limiting micropore blocking and the deposition of polyaromatic hydrocarbons. Recently, Shen and coworkers [10] observed that coke was preferentially deposited at the interstitial voids of nano-sized H-ZSM-5 prior to being generated inside the microporous channels. Thereby, coke is

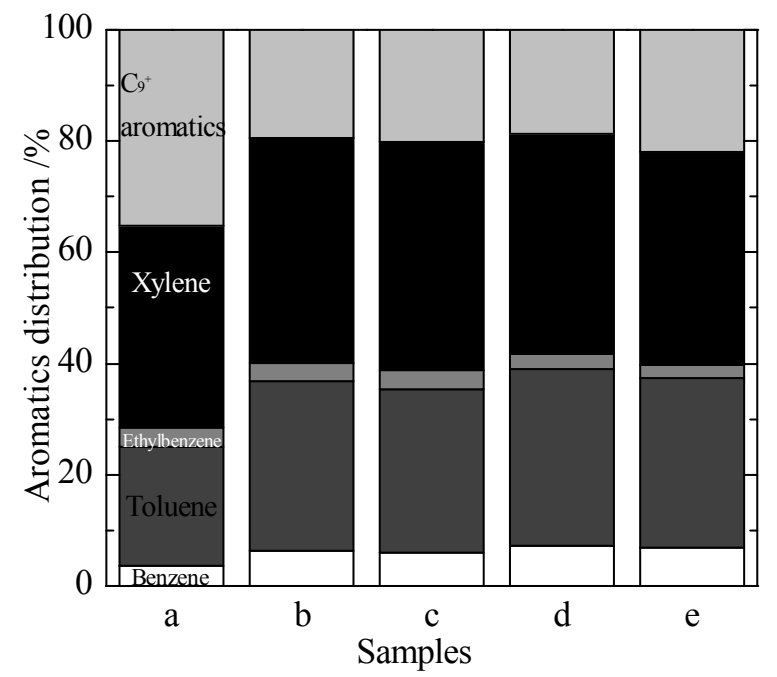

Fig. 7. Distribution of aromatic products including BTX and $\mathrm{C}_{9}{ }^{+}$aromatics obtained at $120 \mathrm{~min}$ on stream. 


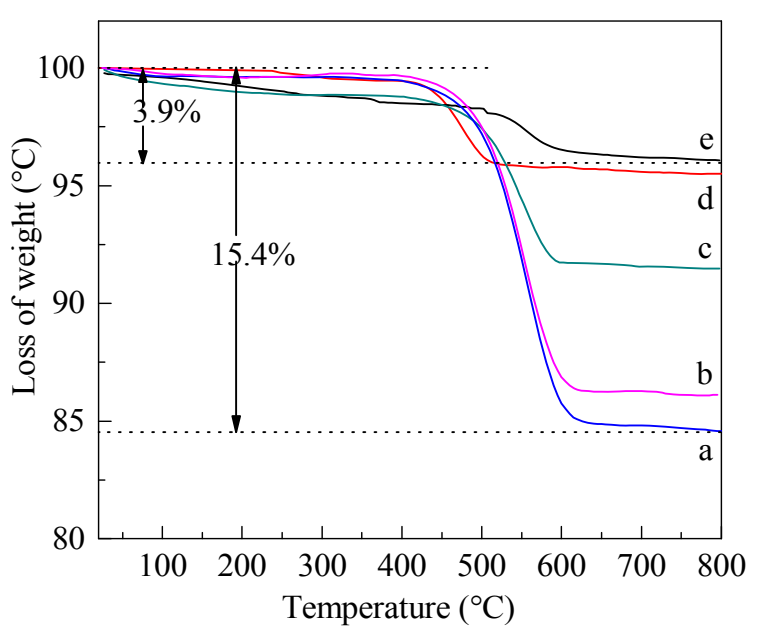

Fig. 8. Thermal gravimetric profiles, under flowing air, of the deactivated catalysts after being subjected to the MTA reaction.

sparingly deposited into the internal channels of nano-sized H-ZSM- 5 because of the unique hierarchical structure and the abundance of pores residing at the large external surface. All of the above results for the aromatization of methanol over the H-ZSM-5 catalysts of differing crystal size clearly indicate that the nano-sized H-ZSM-5 catalyst shows significantly higher activity and enhanced stability than the micro-sized H-ZSM-5 catalysts. The studies of Srivastava et al. [29] on mesoporous materials possessing zeolite frameworks showed that the presence of micropores and mesopores in the hierarchical materials exhibited slow catalytic deactivation for various reactions. The interconnected microporous and mesoporous channel systems of ZSM-5 and MCM-48 were found to enhance the mass transfer properties and reduce diffusion limitations [30]. The presence of mesopores in ZSM-5 improved conversion and reaction yield for the Friedel-Crafts alkylation of toluene with ethane, as reported by Bohström and coworkers [31]. Furthermore, in the acetone-to-olefin reaction, nano-sized zeolites showed higher activity over a longer lifetime compared with the macro-zeolite counterparts [32]. Since the $\mathrm{SiO}_{2} / \mathrm{Al}_{2} \mathrm{O}_{3}$ molar ratios and acidic properties are similar for all the zeolite samples in this study, the higher conversion, longer lifetime and higher activity can be attributed to the abundant microporous and mesoporous formed by the aggregation of the nano-sized particles.

\section{Conclusions}

H-ZSM-5 zeolites were hydrothermally synthesized and control over their crystal size was easily achieved by changes to the TPAOH: $\mathrm{H}_{2} \mathrm{O}$ ratio and crystallization time. The influence of crystal size on methanol conversion in the MTA reaction was studied. Measurements of the textural properties of the H-ZSM-5 show that the specific external surface area and pore volume increase as a function of decreasing crystal size. The nano-sized H-ZSM-5 catalyst shows remarkable selectivity towards aromatics and BTX in the MTA reaction, which is attributed to the short diffusion length, substantial mesoporosity and large external surface area. The hierarchical nano-sized
H-ZSM-5 zeolite catalyst exhibits increased catalytic lifetime, higher activity and low coking levels compared with the larger-sized zeolite analogues, and is potentially advantageous in the continuous flow MTA process.

\section{References}

[1] Y. Bi, Y. L. Wang, X. Chen, Z. X. Yu, L. Xu, Chin. J. Catal., 2014, 35, 1740-1751.

[2] H. A. Zaidi, K. K. Pant, Ind. Eng. Chem. Res., 2008, 47, 2970-2975.

[3] Y. M. Ni, A. M. Sun, X. L. Wu, J. L. Hu, T. Li, G. X. Li, Chin. J. Chem. Eng., 2011, 19, 439-445.

[4] U. Olsbye, S. Svelle, M. Bjørgen, P. Beato, T. V. W. Janssens, F. Joensen, S. Bordiga, K. P. Lillerud, Angew. Chem. Int. Ed., 2012, 51, 5810-5831.

[5] T. Wang, X. P. Tang, X. F. Huang, W. Z. Qian, Y. Cui, X. Y. Hui, W. Yang, F. Wei, Catal. Today, 2014, 233, 8-13.

[6] Y. Inoue, K. Nakashiro, Y. Ono, Microporous Mater., 1995, 4, 379-383.

[7] G. A. Olah, Angew. Chem. Int. Ed., 2005, 44, 2636-2639.

[8] J. Kopyscinski, T. J. Schildhauer, S. M. A. Biollaz, Fuel, 2010, 89, 1763-1783.

[9] H. Baozhai, Y. Yang, Y. Y. Xu, U. J. Etim, Q. Ke, B. J. Xu, Z. F. Yan, Chin. J. Catal, 2016, 37, 1206-1215.

[10] C. S. Cundy, P. A. Cox, Chem. Rev., 2003, 103, 663-702.

[11] K. Shen, N. Wang, W. Z. Qian, Y. Cui, F. Wei, Catal. Sci. Technol., 2014, 4, 3840-3844.

[12] J. Li, S. Y. Liu, H. K. Zhang, E. J. Lü, P. J. Ren, J. Ren, Chin. J. Catal,, 2016, 37, 308-315.

[13] Y. P. He, M. Liu, C. Y. Dai, S. T. Xu, Y. X. Wei, Z. M. Liu, X. W. Guo, Chin. J. Catal., 2013, 34, 1148-1158.

[14] S. Hassanpour, M. Taghizadeh, F. Yaripour, Ind. Eng. Chem. Res., 2010, 49, 4063-4069.

[15] S. Fathi, M. Sohrabi, C. Falamaki, Fuel, 2014, 116, 529-537.

[16] N. Viswanadham, S. K. Saxena, J. Kumar, P. Sreenivasulu, D. Nandan, Fuel, 2012, 95, 298-304.

[17] N. Viswanadham, R. Kamble, M. Singh, M. Kumar, G. M. Dhar, Catal. Today, 2009, 141, 182-186.

[18] N. Viswanadham, S. K. Saxena, Fuel, 2013, 105, 490-495.

[19] M. Firoozi, M. Baghalha, M. Asadi, Catal. Commun., 2009, 10, 1582-1585.

[20] M. Choi, K. Na, J. Kim, Y. Sakamoto, O. Terasaki, R. Ryoo, Nature, 2009, 461, 246-249.

[21] W. Song, R. E. Justice, C. A. Jones, V. H. Grassian, S. C. Larsen, Langmuir, 2004, 20, 8301-8306.

[22] J. Kim, M. Choi, R. Ryoo, J. Catal., 2010, 269, 219-228.

[23] M. Thommes, K. Kaneko, A. V. Neimark, J. P. Olivier, F. Rodriguez-Reinoso, J. Rouquerol, K. S. W. Sing, Pure Appl. Chem., 2015, 87, 1051-1069.

[24] K. A. Cychosz, R. Guillet-Nicolas, J. García-Martínez, M. Thommes, Chem. Soc. Rev., 2016.

[25] K. S. W. Sing, T. W. Ruth, Adsorpt. Sci. Technol., 2004, 22, 773-782.

[26] K. Shen, W. Z. Qian, N. Wang, C. Su, F. Wei, J. Mater. Chem. A, 2014, 2, 19797-19808.

[27] B. Liu, Y. M. Chai, Y. P. Li, A. J. Wang, Y. Q. Liu, C. G. Liu, Appl. Catal. A, 2014, 471, 70-79.

[28] T. Miyamoto, N. Katada, J. H. Kim, M. Niwa, J. Phys. Chem. B, 1998, 102, 6738-6745.

[29] R. Srivastava, M. Choi, R. Ryoo, Chem. Commun., 2006, 4489-4491.

[30] Z. X. Di, C. Yang, X. J. Jiao, J. Q. Li, J. H. Wu, D. K. Zhang, Fuel, 2013, 104, 878-881. 


\title{
Graphical Abstract
}

Chin. J. Catal., 2017, 38: 683-690 doi: 10.1016/S1872-2067(17)62791-8

\section{Correlation between H-ZSM-5 crystal size and catalytic performance in the methanol-to-aromatics reaction}

Lingzhi Yang, Zhiyuan Liu, Zhi Liu, Wenyong Peng, Yunqi Liu*, Chenguang Liu*

China University of Petroleum (East China)

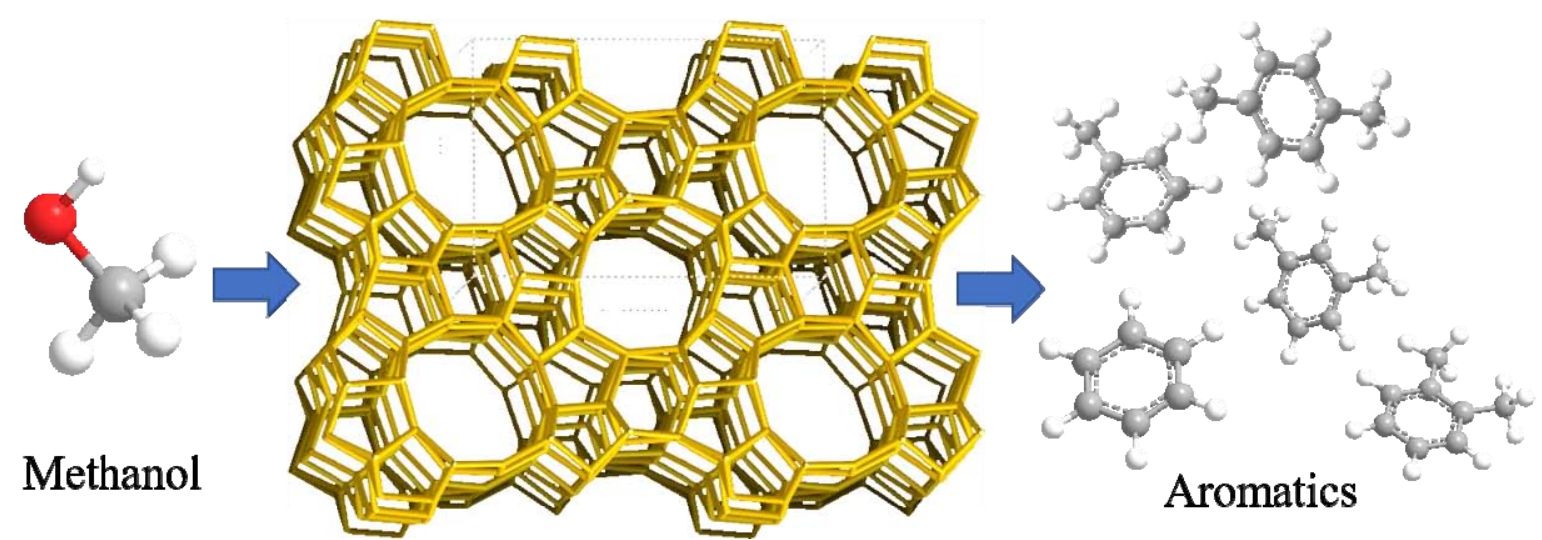

The effect of H-ZSM-5 crystal size on the methanol-to-aromatics reaction has been systematically investigated. Nano-sized hierarchical H-ZSM- 5 shows enhanced catalytic activity attributed to the presence of auxiliary meso- and macropores and larger external surface areas.

[31] B. Zebastian, H. Haerelind, G. Borje, A. Sven-Ingvar, H. Krister, RSC Adv., 2014, 4, 28786-28793.
[32] T. Tago, H. Konno, Y. Nakasaka, T. Masuda, Catal. Surv. Asia, 2012, $16,148-163$.

\section{不同晶粒尺寸H-ZSM-5催化剂上甲醇芳构化反应性能}

\author{
杨灵志, 刘志远, 刘智, 彭文永, 柳云骐 ${ }^{*}$, 刘晨光 ${ }^{*}$ \\ 中国石油大学(华东)化学工程学院重质油国家重点实验室, 山东青岛 266580
}

摘要: 芳烃是一类重要的有机化工基础原料, 通常采用传统的石油路线生产芳烃, 包括催化裂化和催化重整等工艺. 由于 石油资源的紧缺, 以可再生资源为原料生产芳烃工艺的发展具有十分重要的意义. 甲醇作为一种重要的基础原料, 可来源 于煤、天然气和生物质等, 因此, 甲醇制芳烃工艺(MTA)的研究受到日益关注. ZSM-5分子篎具有较大的比表面积、可调节 的酸性、优良的择形选择性和很高的水热稳定性, 因而在甲醇芳构化中展现出良好的催化性能. 研究发现, 甲醇转化率和 产物分布与ZSM-5分子笁的酸性和多孔性等密切相关.

本文通过调控模板剂与水的比例和晶化时间, 采用水热法制备了一系列不同晶粒度H-ZSM-5分子篮催化剂, 通过X射 线衍射(XRD)、扫描电镜(SEM)、 $\mathrm{N}_{2}$ 物理吸附脱附(BET)和X射线荧光光谱等技术对所得分子篎的理化性质、骨架结构和 形貌进行了表征; 采用吡啶红外光谱和 $\mathrm{NH}_{3}$ 程序升温脱附技术对其酸性进行了分析, 使用热重(TG)技术对反应后催化剂的 积碳含量进行了分析, 并将所制备的H-ZSM-5 分子篮催化剂分别应用于MTA反应, 系统性地探究分子篮晶粒度对其理化性 质和MTA催化性能的影响.

XRD结果表明, 所合成的五种样品均具有典型的ZSM-5分子笁特征衍射峰且无杂晶, 且具有不同的晶粒度, 分别为4.0 $\pm 0.3,1.2 \pm 0.2 \mu \mathrm{m}, 614.1 \pm 31.9 、 391.9 \pm 32.4$ 和 $99.1 \pm 7.0 \mathrm{~nm} . \mathrm{N}_{2}$ 物理吸附脱附曲线可以发现, 晶粒度为 $99.1 \pm 7.0 \mathrm{~nm}$ 的 ZSM-5分子笁展现出典型的I型和IV 型物理吸附曲线且在较高的相对压力 $\left(p / p_{0}=0.8-1.0\right)$ 处有一个明显的 $\mathrm{H} 4$ 型迟滞环, 表 明此分子篮具有介孔和大孔结构; BJH吸附孔径分布图表明, 这些介孔主要分布在2-7和20-50 nm范围内; 同时各样品的 比表面积和孔体积随着其晶粒度的减小而增大. 结果还表明五种不同晶粒度的 ZSM-5 分子篎具有相似的 $\mathrm{SiO}_{2} / \mathrm{Al}_{2} \mathrm{O}_{3}$ 摩尔比 和酸性质.

MTA反应结果表明, 随着催化剂晶粒度的降低, 甲醇的平均转化率, 芳烃选择性和BTX选择性有所提高, 在 $300 \mathrm{~min}$ 时 晶粒度较大的三个催化剂上, 甲醇转化率迅速降至 $90 \%$, 而晶粒度较小的两个催化剂上, 甲醇转化率始终维持在 $95 \%$ 以上, 其中晶粒度为 $99.1 \pm 7.0 \mathrm{~nm}$ 的样品上芳烃选择性最高(平均 $42 \%$ 以上), BTX选择性达 $37 \%$. 对失活催化剂积碳含量分析, 随 着催化剂晶粒度的降低, 积碳量降低. 
晶粒度较低的纳米分子耖催化剂具有更短的孔道, 更高效的扩散性能, 更高的比表面积和独特的梯级孔结构, 因而在 甲醇芳构化反应中展现出更长的寿命, 更高的活性和更低的积碳量, 在甲醇制芳烃工业化生产中具有巨大潜力.

关键词: 甲醇; 芳烃; 纳米H-ZSM-5分子笁; 梯级孔结构; 晶粒大小

收稿日期: 2016-11-29. 接受日期: 2017-01-13. 出版日期: 2017-04-05.

*通讯联系人.电话: (0532)86981861; 电子信箱: liuyq@upc.edu.cn

\#通讯联系人. 电话: (0532)86981716; 电子信箱: cgliu@upc.edu.cn

基金来源：国家自然科学基金(21676300).

本文的英文电子版由Elsevier出版社在ScienceDirect上出版(http://www.sciencedirect.com/science/journal/18722067). 